\title{
Research on Implementation Strategy of Lean Construction Management in Chinese Construction Enterprises
}

\author{
Yan Liao \\ School of Architecture and Materials \\ Chongqing College of Electronic Engineering \\ Chongqing, China
}

\begin{abstract}
Under the new situation of China's economy, lean construction management can help construction enterprises improve their management level and economic benefits, and promote the transformation and upgrading of construction enterprises. Based on the analysis of the status quo of lean construction management in China's construction enterprises, this paper finds the weak spots in the implementation of lean construction in China and puts forward some strategies to promote the implementation of lean construction against these problems in order to provide reference for the development of lean construction in China's construction enterprises.
\end{abstract}

Keywords-lean construction; construction enterprises; weak spot; strategy

\section{INTRODUCTION}

In recent years, the scale of the construction industry in China has been constantly expanding, showing the momentum of sustained and rapid growth and has become a pillar industry in the development of the national economy. However, the low profit margins, low industrial concentration, high labor costs, serious waste of resources and low technological content have hindered the sustainable development of the construction industry. Under the new situation of China's economy, how to cultivate and maintain the competitive advantages of construction enterprises and promote the transformation and upgrading of the construction industry are important issues to be resolved urgently. Some scholars have pointed out that the lack of clear theoretical guidance is the main reasons that hinder the development of the construction industry [1]. Construction enterprises urgently need to introduce advanced production management and scientific production management theory, to seek suitable development path

\section{IMPLEMENTATION STATUS AND EFFECTIVENESS OF LEAN CONSTRUCTION MANAGEMENT IN CHINESE CONSTRUCTION ENTERPRISES}

\section{A. Meaning of Lean Construction Management}

In the past 20 years, the great success of Lean Thinking and its management methods in the traditional manufacturing industry, especially in the automotive industry, has aroused great interest and widespread concern of the construction industry experts and scholars [2]. In 1992, Koskela put forward that applying "Lean Thinking" to the construction industry can greatly improve the current status of the construction industry [3], and first proposed the concept of "Lean Construction (LC)" at the IGLC (International Group of Lean Construction) convention in 1993 [4]. So far, lean construction has been widely studied and practiced in the United States, Britain, Denmark, Singapore and other countries [5] [6].

Since 2005, some Chinese construction enterprises have begun to gradually implement lean construction management. This article defines lean construction as follows: lean construction is a management style, and is a management concept and the embodiment of corporate culture; It is developed under the strong support of Lean Production Theory, and combining with the one-time and complexity of construction projects, and it incorporates the key technologies of Lean Construction. Its goal is to continuously and dynamically improve and manage construction projects so as to eliminate waste, maximize customer value and help enterprises achieve overal economic efficiency improvement.

\section{B. The Status Quo of Lean Construction Management in Chinese Construction Enterprises}

Through the data collection, investigation and interviews with China's lean construction management implementation cases, we found that there are not many construction enterprises that implement lean construction mode. At present, only some enterprises with strong comprehensive strength can use the lean construction management mode to carry out enterprise management reform. They implement 
lean construction management mainly in the following three forms:

1) Lean construction management: At present, there are some construction enterprises that have made clear changes in the company's management model by explicitly using the name "lean construction". Such as, China Construction Eighth Engineering Bureau Division. Corp. LTD, China Construction Fifth Engineering Bureau Division. Corp. LTD, China Construction Third Engineering Bureau Division. Corp. LTD and so on. The lean construction management mode they used is derived from the TFV theory put forward by western countries, which has strong theoretical basis, and it can also use various key technologies in lean construction management.

2) Japanese style management: In the case of the research, there are some construction enterprises that implemented the new management model called "Japanese style management". Such as Zhongtian construction group, Kunxing construction group and so on. The Japanese style management model implemented by these enterprises comes from the construction enterprise management in Japan, and its theoretical basis is from the "TOYOTA model" in Japan. Their Japanese style management is very close to the model of construction enterprise management in Japan. For example, the $5 \mathrm{~S}$ field management, visual management, safety production cycle management, interpenetration construction are the management contents of Japan's Dacheng construction enterprise, and they are also being implemented in Zhongtian and Kunxing construction group.

3) Detail management: Though the concept of management mode put forward by some enterprises is not the name of lean construction, its goal and execution way is essentially the content of lean construction management. They are based on the standardization requirements and take the customer's demand as the ultimate goal, and through the standardized management to eliminating waste in the process and maximizing the value. For example, the management philosophy put forward by China Hydropower fourth Bureaus is "Three Excellences" and others are implementing "standardized management" and "lean management" to create "quality projects".

Combined with the current implementation of lean construction management, we can find that lean construction and Japanese style management all originate from the Japan's Toyota production, and are the two branches of it. The detail management is based on standardization, and the standardization is also a major feature of Toyota production. So the three types of lean construction are of the same origin. Their objectives and methods are consistent. They are different stages of development and different forms of implementation shown in lean construction management. It is shown as "Fig. 1".

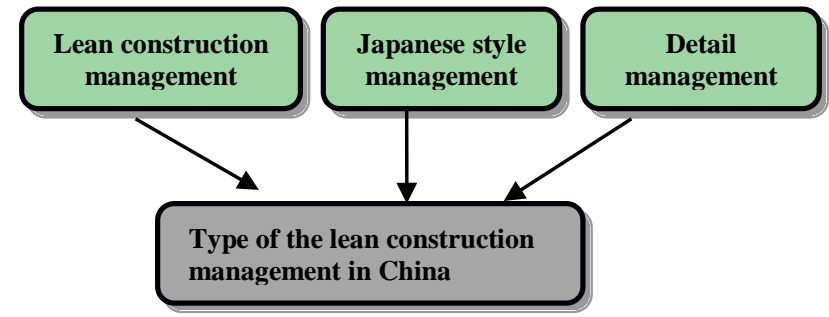

Fig. 1. Implementation types of lean construction management in Chinese construction enterprises.

\section{Implementation Results of Lean Construction Management in Chinese Construction Enterprises}

Chinese construction enterprises achieved remarkable results through the implementation of lean construction management mode, which brought substantial benefits to enterprises, and also stimulated the enthusiasm of employees. The details are listed in "Table I".

TABLE I. A STATISTICAL TABLE ON THE IMPLEMENTATION RESULT OF LEAN CONSTRUCTION MANAGEMENT IN CHINESE CONSTRUCTION ENTERPRISES

\begin{tabular}{|l|l|}
\hline \multicolumn{1}{|c|}{ Enterprise Name } & \multicolumn{1}{|c|}{ Implementation result } \\
\hline $\begin{array}{l}3^{\text {rd }} \text { Construction. } \\
\text { CO. LTD of China } \\
\text { construction 5 } \\
\text { engineering bureau }\end{array}$ & $\begin{array}{l}\text { With standardization and modularization } \\
\text { requirements, employees' understanding of job } \\
\text { responsibilities is accelerated, and their annual } \\
\text { revenue growth is about 14\% [7]. }\end{array}$ \\
\hline $\begin{array}{l}\text { Jiangsu Wujin } \\
\text { Construction Group } \\
\text { Cailiang Branch }\end{array}$ & $\begin{array}{l}\text { The building 58 of Jiuzhou Garden Phase III, in } \\
\text { Changzhou, reduces the labor and the space } \\
\text { waste, and shortens the construction period by }\end{array}$ \\
$\begin{array}{l}18 \% \text { or more by the lean construction } \\
\text { management [8]. }\end{array}$ \\
$\begin{array}{l}\text { Since 2010, the Company has implemented } \\
\text { lean production. In the following three years, } \\
\text { Construction Group } \\
\text { the average profit (gross profit) of the } \\
\text { Company's projects has increased by 6.91\% per } \\
\text { annum, and creating a total profit of 12.21 } \\
\text { million yuan [9]. }\end{array}$ \\
$\begin{array}{l}\text { Companies uses the "Japanese style } \\
\text { management" to effectively short the } \\
\text { construction period of about 25\%; reduces } \\
\text { Chongtian } \\
\text { construction } \\
\text { enterprise }\end{array}$ \\
$\begin{array}{l}\text { collective procurement, can reduce construction } \\
\text { waste 83\% and second refurbishment [10]. }\end{array}$ \\
\hline
\end{tabular}

It can be seen from the above table that the construction enterprises can shorten project duration through lean construction management, save project costs, reduce material waste, achieve the overall efficiency of the company, and win the market recognition for enterprises. At the same time, lean construction management promotes full participation and teamwork, and strengthens communication between superiors and employees, and raises income for employees. So it can be seen that the lean construction management have a great practical significance in the application of Chinese construction enterprises. Weak point of the lean construction in China.

\section{WEAK POINT OF THE LEAN CONSTRUCTION IN CHINA}

Although the implementation of lean construction management has achieved some success, but this management approach comes from the experience of 
developed countries, and China's national conditions and developed countries are completely different, the current implementation of lean construction management is no largescale promotion and application. So it can be seen that there are still weak points in its implementation. The paper mainly summarized as the following aspects:

\section{A. Missing the Lean Construction Culture in the Construction Enterprise}

When promoting the lean construction management, the enterprise can assimilate into the cultural elements, but more attention is lean construction technology. Most aspects of management tend to use the lean construction technology. They focus on how to directly apply the key technologies of lean construction such as 5S management, Kanban management and standardization to realize the control of quality, cost and construction period. For example, the some managers of the $1^{\text {st }}$ Construction. CO. LTD of China construction $3^{\text {th }}$ engineering bureau mentioned that owners, contractors and supervisors initially took part in daily morning meetings on time, but as time went by, workers began to relax and attend fewer and fewer participants. All of these phenomena show that in the process of implementing lean construction, everyone is concerned with the implementation of lean technologies, while ignoring the input of culture and the employees are not consciously improving themselves.

\section{B. Shortage of Technical Talents}

The Project manager in the case of construction enterprises found that because of the unevenness technical level of construction, it directly affected the quality of construction procedures; unevenness of the technical level of construction workers directly affected the quality of construction procedures; Some new technologies introduced by workers in lean construction cannot grasp the essentials; And the workers are poorly managed and migrate and cannot keep them continuously trained. Most of these construction workers are migrant workers and are the main force in the construction industry workers in China. According to the statistics of China's National Bureau of Statistics, in 2016, 55.5 million migrant workers were employed in the industry in China, while migrant workers accounted for construction more than $80 \%$ of the construction workers. Some $74 \%$ of migrant workers had junior high school education and $64.9 \%$ of migrant workers do not sign labor contracts with their employer [11]. The cultural quality and skill level of migrant workers fail to meet the requirements of industrial workers, resulting in a serious shortage of skilled personnel in the construction industry.

\section{Lack of Communication and Cooperation among the Participants}

At present, the most widely used project management mode in China's construction industry is the DBB mode that is the design-bidding-construction mode, also known as the traditional project management mode. In this management model, the design and construction are separated, the owners can choose the design and construction units independently and manage each phase of the construction project. However, at the same time, there are many participants in the entire project and their respective interests are the center. All the operational links are independent and are prone to all kinds of conflicts and disputes. Information sharing is not achieved and teamwork is lacking. All parties ignore the real needs of the owners, so it results the entire inefficient situation in project management. All these will hinder the implementation of lean construction mode.

\section{PROPOSALS FOR IMPLEMENTING LEAN CONSTRUCTION MANAGEMENT IN CONSTRUCTION ENTERPRISES IN CHINA}

\section{A. Agglomerating the Enterprise Culture for Lean Construction}

Lean construction culture is to tell the staff the new management method for lean construction. Employees should be able to consciously implement lean technology in everyday life without supervision, and should commit to continuous improvement and eliminate waste in lean construction. The top management of the company needs to implement organizational change within the enterprise, change employee behavior, demonstrate the passion for change, and convey the concept of lean construction to all employees.

\section{B. Paying Attention to Leadership Training and Staff Training}

The leader is the spiritual pillar of the employee. In lean construction management, we first need leaders to thoroughly understand the concept of lean construction management, and have a long-term and unwavering support for the lean construction management. Secondly, leaders must understand the lean construction management system and their responsibilities, and emphasize the training of lean construction management skills and professional knowledge, and also should make up for the lack of general leaders' professional skills, and make employees more respected, trusted and willing to follow the leaders. Finally, the leader can continue cultivation and development of employees, to continuously build lean training for employees, so that the employees can understand the concept of lean construction and implementation requirements, and have a common sense to achieve lean constructions.

\section{Developing Enterprise Partners}

The implementation of lean construction management requires the participation of all parties to fully understand the core ideas of lean construction. First of all, we should create a fair, honest and mutual respect business environment for the partners, and clarify the complex chain relationship between the partners. Secondly, through site research, the partners and the construction enterprises can understand each other's design and production process, and technical operation ability, and can make clear the needs of construction enterprises, to timely delivery the products needed. Through the cooperation, enable the partners to participate in the transformation of production management 
mode. The working mode of partners can be adapted to the construction enterprises. Finally, through this long-term, resource intensive mutual understanding and coordination, it can help construction enterprises to develop the core partnership. In the long-term cooperation, the construction enterprises and the participants can learn from each other, learn and improve together, and finally achieve the goal of mutual growth and mutual growth for a long time.

\section{CONCLUSION}

Through the case study of construction enterprises in the construction management of the lean Chinese, the paper summarizes the type and results of current lean construction, and it is finds that lean construction management can improve the overall efficiency of construction enterprises, and it is very practical to the enterprises. However, the implementation of lean construction management has the weakness of the lack of corporate culture, the shortage of skilled personnel, and the lack of communication and cooperation. Therefore, aiming at these weaknesses, the paper puts forward three strategies to promote the implementation of lean construction management in Chinese construction enterprises by changing corporate culture, staff training and maintaining good cooperative relationship. Due to the complexity and variability of construction projects, the lean construction management of Chinese construction enterprises is not mature enough in theory and practice and it still needs further discussion. I hope this article can provide reference for further development and improvement.

\section{REFERENCES}

[1] Cao Jiming. Engineering construction management[M]. China Construction Industry Press, 2010

[2] Womack J P. and Jones D T. Lean Thinking[M]. New York: Simon and Schuster, 1996.

[3] Koskela L. Application of the new production philosophy to construction[M]. Stanford, CA: Stanford university, 1992.

[4] Koskela L. Lean Production in Construction, IGLC-1[C]. Espoo, Finland, 1993:1-9

[5] Mossman, Alan. Why isn't the UK Construction Industry Going Lean with Gusto?[J]. Lean Construction Journal, 2009:24 -36

[6] Thomassen M A, Sander D, Barnes K A, et al. Experience and results from implementing lean construction in a large Danish contracting firm[C]. Proceedings of 11th Annual Conference on Lean Construction, 2003: 644-655.

[7] Hu Guangjun. Using standardized management to lead the future of Enterprises[J]. Architecture, 2010,16: 19.

[8] China Construction newspaper Policy Research Center "lean construction" model group, A summary of the "lean construction" model[N]. China Construction News, 2017-3-8(014).

[9] Xu Yuanfei, Yin Haibin, Yin Fenghua. Lean production in site -- the lean production mode in the construction site[J]. China Quality, 2015, 8: $17-20$.

[10] Dong Mei. An empirical analysis based on the fine management in Wanke group[J]. Cuide to Business, 2014(12): 70-71.

[11] State Statistical Bureau. Survey report on migrant workers' monitoring in 2016[R]. 2017. 